\title{
RD efluoridation of Groundwater using Natural Bio Adsorbents
}

\author{
Susmitha Sambaraju, Sree Lakshmi
}

\begin{abstract}
Fluoride is every now and again delineated as a 'twofold edged sword' as lacking ingestion is connected with dental caries, where as excessive confirmation prompts dental, skeletal and fragile tissue fluorosis-which has no fix. Considering how fluorosis is an irreversible condition and has no fix, balancing activity is the principle answer for this peril. Giving water, with perfect fluoride center is the principle course by which the age yet to be imagined can be totally verified against the ailment. Defluoridation was the customary and comprehensively attempted procedure for giving safe water to the fluorosis impacted systems. Various techniques and materials were endeavored all through the world for defluoridation of water. Defluoridation frameworks can be widely described in to four orders; Adsorption methodology, Particle exchange technique, Precipitation system, and Different methodologies, which join electro compound defluoridation and Invert Assimilation. Among all significant defluoridation strategies, the Nalgonda procedure is the most effective and generally utilized method for defluoridation. Nevertheless, there is an especially need to build up a feasible system that is practical and easy to understand.In present investigation, rice husk and eggshell powder are utilized as adsorbents to evacuate the fluorides in water. The cluster contemplates uncovered that these normal materials have high expulsion productivity, which is significantly affected by the measurement content, Ph, contact time. Additionally diagrams are utilized to analyze the efficiencies of practical and traditional procedures.
\end{abstract}

Index Terms: Fluoride in drinking water, Various techniques in fluoride contamination, Nalgonda techniques

\section{INTRODUCTION}

Groundwater is the significant source in many pieces of the world for different purposes. The nearness of low or high grouping of specific particles is a critical issue as they make the groundwater unfit for various applications. Fluoride is one such particle whose nearness in water is both valuable and detrimental. Fluorine is the thirteenth most plenteous component and is about $0.3 \mathrm{~g} / \mathrm{Kg}$ of earth's outside layer.

It is a component of halogen bunch with nuclear number 9 and sub-atomic weight 19.

Revised Manuscript Received on November 19, 2019

SUSMITHA SAMbaraju IS PURSUING HER B.TeCH AT KONERU LAKSHMAIH EDUCATION FOUNDATION (DEEMED TO BE UNIVERSITY), VADDEESWARAM, GunTUR District, ANDHRA PRADESH,

Sree Lakshmi is working as Assistant Professor at Koneru Lakshmiah Education Foundation (Deemed to be University), Vaddeswaram, Guntur district, AndhraPradesh

It is the lightest component of the halogen bunch in the intermittent table and has a solitary stable isotope, Fluorine is a light yellow gas made out of diatomic particles at standard weight and temperature. fluorine-19. Of the considerable number of components fluoride is the most receptive and electronegative as a result of its little sweep/charge proportion. Thus, it is considered as the most electronegative component and furthermore have low separation vitality. This makes fluorine a profoundly responsive and have solid liking to join with different components to deliver different mixes Because of its little sweep, it tends to go about as ligand and effectively of these mixes are very dissolvable in water, so fluoride is completely separated in surface and groundwater as a fluoride particle. In the earth crust, it is about $0.3 \mathrm{~g} / \mathrm{kg}$ and fluoride is the 13th most abundant element. And it's a halogen group of molecular weight 19 and atomic number 9. It's a diatomic molecule at standard temperature and pressure. It's a single stable isotope, fluorine -19 and lightest element in the halogen group in the periodic table. Due to the small radius/charge ratio fluoride elements is the most electronegative, most reactive and it has low dissociation energy. It makes a highly reactive and strong affinity to produce various compounds. And its characterized by a small radius, distinct inorganic and organic compounds in rocks, air, plants, and animals. And it's quite soluble in water is almost in surface and groundwater as a fluoride ion.
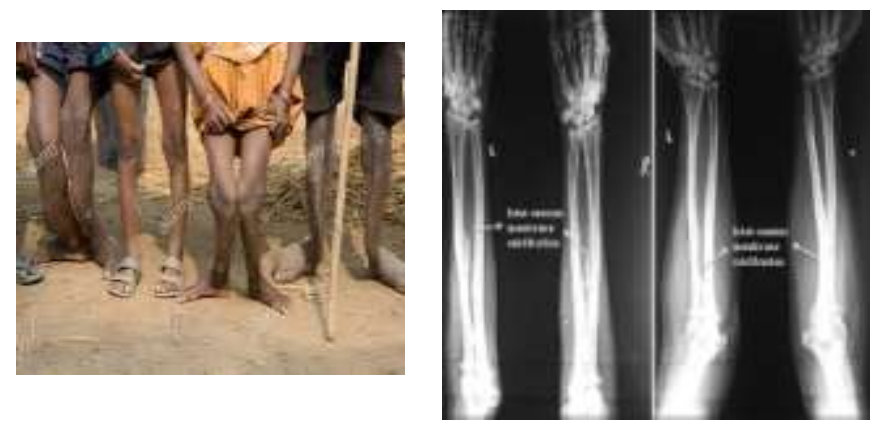

Fig. 1 Skeletal Fluorosis

\section{SOURCES}

Water, food, air, medicines, and cosmetics are the main sources of fluoride in humans. Studies have shown that about $60 \%$ of the total fluoride intake is through drinking water.

Rocks: When compared with surface water groundwater is more contaminated with fluoride. 


\section{RD efluoridation of Groundwater using Natural Bio Adsorbents}

This is because rocks act as a source of fluoride when water passes or percolates through these rocks, it leaches out the fluoride from these rocks. Some of the most common rocks which are rich in fluoride are cryolite, fluorapatite, $\mathrm{CaF} 2$, WHO suggested a level of fluoride from $0.5-1 \mathrm{ppm}$ is safe. In many countries, dental cavities are of major concern affecting $60-90 \%$ of school children and the majority of adults and the factors governing the release of fluoride into the water from fluoride bearing minerals are chemical composition of the water presence and accessibility of fluoride minerals to water, contact time between the source mineral and water.

Anthropogenic: Agricultura phosphate fertilizers contribute to fluoride in irrigation lands, mining and combustion activities of coal. Coal is one of the potential sources of fluoride are combusted in various industries and brick kilns, Improper disposal of fly ash In these activities fluoride is emitted in gaseous form and finally reaches the surface and during rainfall, they percolate into the ground and thereby increasing the fluoride content.

\section{EFFECTS}

In India the harmful effects of high consumption of fluoride on humans and animals was discovered in 1937. Since then, in many areas of India and around the globe, there has been a lengthy history of fluorosis observation. Harmful levels of fluoride: A daily consumption of about $10-20 \mathrm{mg} /$ day was discovered to be damaging for adults and as low as 3-8 mg/ day for kids. In this context, safety limits of 1-1.5 ppm of fluoride in drinking water have been arrived in India. The permissible consumption of fluoride is recommended to be $0.05 \mathrm{mg} / \mathrm{day} / \mathrm{kg}$ of body weight for maintaining good health. The average weight of rural Indian is about 50 to $60 \mathrm{~kg}$.

1.Thus per day permissible consumption of fluoride is about 2. 5 to $3 \mathrm{mg}$.

2. Bureau of Indian Standards (BIS)-0.6 to $1.2 \mathrm{mg} / \mathrm{lit}$.

3. World health Organization (WHO-1984 ) for drinking water-1 to $1.5 \mathrm{mg} / \mathrm{lit}$.

4. Indian Council of Medical Research (ICMR-1975)-1 $\mathrm{mg} / \mathrm{lit}$.

5. World Health Organization (WHO) European Standards0.7 to $1.7 \mathrm{mg} / \mathrm{lit}$ related to temperature.

As fluoride is one of the most bone seeking elements known to humans, daily intake of just 2 milligrams of fluoride could lead to skeletal fluorosis. After the age of 40 . Several diseases, like osteoporosis, arthritis, brittle bones, cancer, infertility in women, brain damage, Alzheimer's disease and thyroid disorders are caused due to excess intake of fluoride. Nearly half of the daily consumption of fluoride is retained and absorbed by the bones and teeth. For the first time in 1938 it was found that $1 \mathrm{ppm}$ of fluoride in water prevents dental caries whereas more than $1.5 \mathrm{ppm}$ causes mottled teeth

\section{BASE PAPER}

R. Bhaumik, N. K. Mondal et al: Eggshell Powder as an Adsorbent for Removal of Fluoride from Aqueous Solution: Equilibrium, Kinetic and Thermodynamic Studies, Eggshells from the neighborhood markets were gathered and pretreatments like washing with deionized water, warming the shells at a temperature of $105^{\circ} \mathrm{C}$ and smashing were finished. The necessary adsorbent is gathered subsequent to sieving (60-100 work/0.25-0.104 mm) . Trials were led in the research center to assess the impact of adsorption of fluoride from the water. Tests were tried with various $\mathrm{pH}(4-10)$, contact time ( 0-80 min), fluoride focus ( $3-12 \mathrm{ppm})$ and adsorbent measurement (1-2.5 g/l). For homogeneous blending attractive stirrer was utilized at $120 \mathrm{rpm}$. For $\mathrm{pH}$ modification chloric corrosive and sodium hydroxide arrangements $(0.1 \mathrm{~N})$ were utilized. The exploratory discoveries demonstrate that the powdered chicken eggshell is a down to earth and promising strategy for treating fluoride polluted water. Ideal conditions are $\mathrm{pH} 6$, response time 60 mins.

Sumana Ghosh, et al: A Novel Technique for Fluoride Removal from Drinking Water using Rice Husk Charcoal, Rice husk debris has great adsorbent properties due to its high silica content . henceforth in the present investigation rice husk is utilized as an adsorbent for the expulsion of fluoride from water. Rice husk is gathered from the neighborhood factories and the material going through $300 \mu \mathrm{m}$ and holding on $150 \mu \mathrm{m}$ was gathered. In a suppress heater at $300^{\circ} \mathrm{C}$, dried rice husk pressed in a tin compartment with various pores is kept for 3 hours. Along these lines rice husk initiated charcoal (RHAC) is gotten. A channel is structured so that layers of sand and rock are sandwiched between rice husk layers in a 8 " width section. The outcomes presumed that the planned channel can evacuate fluoride with an effectiveness of over $85 \%$. The minimal effort channel is perfect for provincial regions where the groundwater is defiled with high fluoride levels.

Nedunuri Phani Kumar et al: defluoridation of water using tamarind (Tamarindus Indica) fruit cover: Kinetics and equilibrium studies, In the ebb and flow explore, defluoridation of water was completed utilizing Tamarind organic product spread (TNFC) as a characteristic adsorbent in both virgin and corrosive treated structures. Adsorbents are gathered from the neighborhood advertise. The organic product spreads are then washed with refined water for staining and is broiler dried at $1000 \mathrm{C}$ for 30 minutes. It is then powdered and sieved. Half of this powder was drenched for 24 hours in $1 \mathrm{M} \mathrm{HCl}$ and kept for thirty minutes in the water shower $\left(70^{\circ} \mathrm{C}\right)$. It is cooled and with $50 \mathrm{ml}$ of $1 \mathrm{~N} \mathrm{NaOH}$ is killed. At long last it was cleaned a few times with refined water and dried for 6 hours in a stove at $80 \mathrm{oC}$ and cooled in desiccators at room temperature.

A.S. Parlikar, S.S. Mokashi: Defluoridation Of Water by Moringa Oleifera-A Natural Adsorbent, The present examination includes the expulsion of fluoride from water utilizing seeds of Moringa Oleifera. Drumstick (Moringa Oleifera) powder was gathered from nearby trees for planning adsorbent powder. For corrosive treatment $400 \mathrm{ml}$ of $1 \mathrm{~N}$ HNO3 and for soluble base treatment $400 \mathrm{ml}$ of $0.5 \mathrm{~N} \mathrm{NaOH}$ was added to $40 \mathrm{gm}$ of powdered example. At that point the entire blend is bubbled for around 20 minutes. 
The sample is then washed utilizing refined water until most extreme shading was evacuated. It was then stove dried at $50^{\circ} \mathrm{C}$ for 6 hours. Moringa Oleifera seed powder treated with soluble base was found to be superior to Moringa Oleifera seed powder treated with corrosive for fluoride particle removal. Adsorption expulsion was seen to be ideal at 400 $\mathrm{mg} / \mathrm{lit}$ adsorbent portion

\section{TEST CONDITION AND SETUP}

NALGONDA TECHNIQUE: This procedure was created by National Environmental Engineering Research Institute (NEERI), Nagpur and in the long run advanced as basic and affordable strategy for evacuation of fluoride. Nalgonda Method includes option of Aluminium salts, lime and fading powder pursued by quick blending, flocculation, sedimentation, filtration and disinfection. Aluminum salt can be included as alum or aluminium chloride or mix of both. Lime included aides for the development of thick rushes for fast settling. Blanching powder helps in giving sterilization. This procedure is appropriate for both little and enormous networks.Studies are conducted taking $250 \mathrm{ml}$ of sample water. The initial fluoride content is determined using the spectrophotometer and it is found to be $12.5 \mathrm{mg} / \mathrm{l}$. The removal efficiencies of different adsorbents are effected by many parameters such as the dosage, contact time, $\mathrm{pH}$ of the sample taken etc. Experiments are performed with dosages varying from $3 \mathrm{mg} / 250 \mathrm{ml}$ to $18 \mathrm{mg} / 250 \mathrm{ml}$ and the contact period varying from 0.5 hour - 6hours.

\section{STUDY AREA}

Nalgonda locale is situated in Telangana territory of India with 59 mandals and 1175 grama panchayats. As indicated by 2011 statistics populace is around $3,483,648$. Of the 59 mandalas 48 were found to have fluoride issue. Water, surface water and groundwater are the three fundamental water sources in the region. In spite of the fact that water is unadulterated because of its vulnerability one can not depend on it. Waterways streaming in the area are non lasting, coming to streams a stream close sivannagudem has fluoride levels around $7 \mathrm{ppm}$. Groundwater here has significant levels of fluoride and the explanation behind this is seen as low calcium content in rocks and soils and elevated levels of bicarbonates in soil and water. There are an aggregate of 3325 residences in the region where 1440 homes are been provided with surface water from Krishna waterway under 14 unique plans. As indicated by India Water Portal there are around 5.5 lakh profound water bore wells and 16403 hand siphons.

\section{METHODOLOGY}

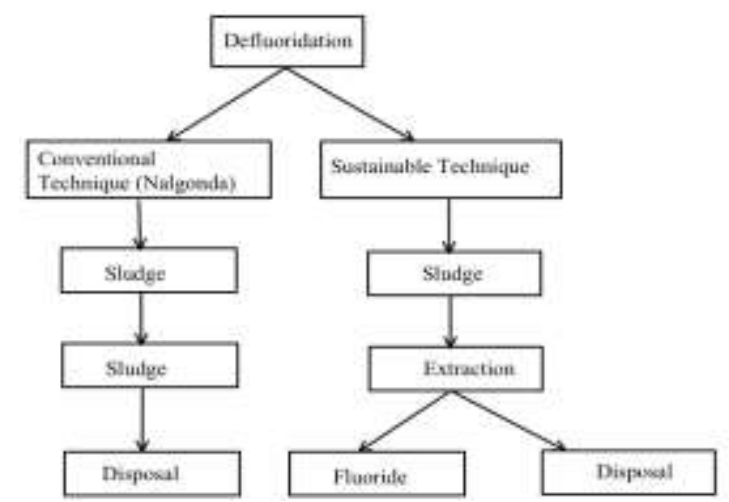

Fig. 2 Process of Defluoridation

\section{LABORATORY EXPERIMENTS}

EFFECT OF PH: With increase in the $\mathrm{pH}$ of the sample, the negative charge increases and the removal efficiency of the adsorbent decreases due to coloumbic forces between negative charges due to hydrogen ions and the fluoride ions. If the $\mathrm{pH}$ is less, the removal efficiencies of the adsorbents is more,

EFFECT OF CONTACT TIME: The adsorption capacity increases with increase in the contact time. As the adsorbent surface attracts the negatively charged fluorides during the contact time, the free surface of the adsorbent is slowly occupied with the fluorides.

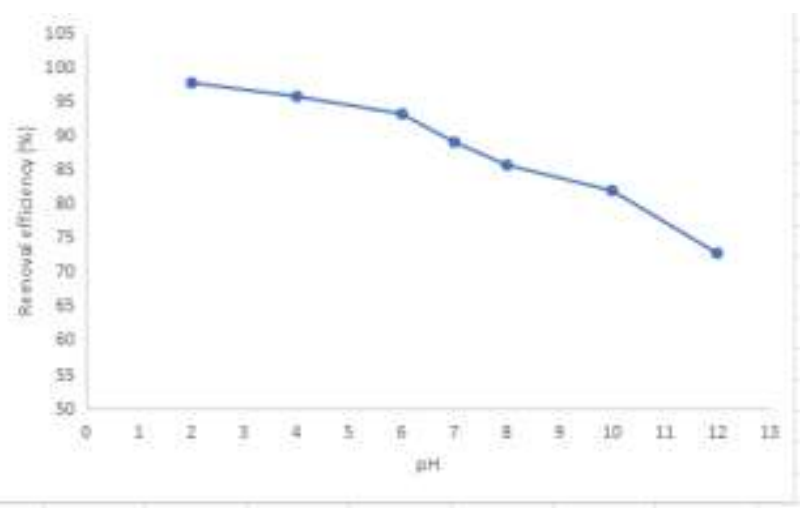

Fig 3 Removal efficiency vs pH (Graph)

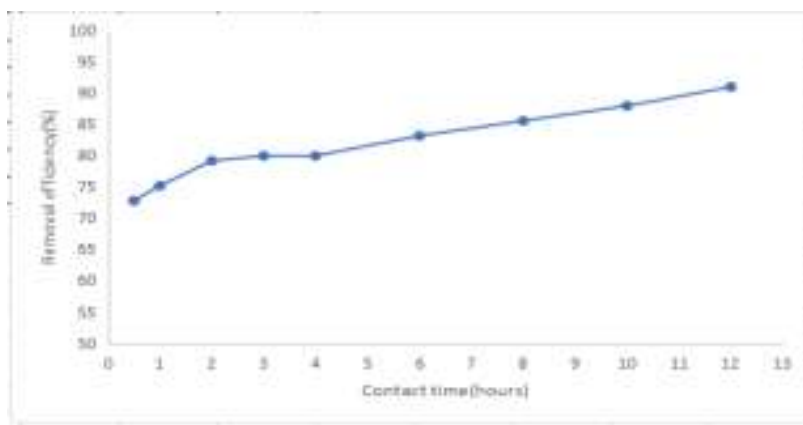

Fig 4 Removal efficiency vs Contact period (Graph) 
RD efluoridation of Groundwater using Natural Bio Adsorbents

NALGONDA TECHNIQUE

\begin{tabular}{|c|c|c|c|c|}
\hline \multicolumn{2}{|c|}{ PPM } & \multirow{2}{*}{$\begin{array}{l}\text { Initial } \\
(\mathrm{ppm})\end{array}$} & \multirow{2}{*}{$\begin{array}{l}\text { Final } \\
(\mathrm{ppm}) \\
\end{array}$} & \multirow{2}{*}{$\begin{array}{l}\text { Removal } \\
\text { efficiency }\end{array}$} \\
\hline Lime & Alum & & & \\
\hline 500 & 30 & 4 & 2.9 & 27.5 \\
\hline 500 & 60 & 4 & 1.4 & 65 \\
\hline 1000 & 30 & 4 & 2.6 & 35 \\
\hline 1000 & 60 & 4 & 1.1 & 72.5 \\
\hline
\end{tabular}

Tabe 1 Removal efficiency (Experimental Results)

RICE HUSK (VARYING CONTACT TIME)

\begin{tabular}{|c|c|c|}
\hline $\begin{array}{c}\text { Contact period } \\
\text { (hrs) }\end{array}$ & $\begin{array}{c}\text { Residual } \\
\text { fluoride }\end{array}$ & $\begin{array}{c}\text { Percentage of } \\
\text { removal }\end{array}$ \\
\hline 0.5 & 3.4 & 72.8 \\
\hline 1 & 3.1 & 75.2 \\
\hline 2 & 2.6 & 79.2 \\
\hline 3 & 2.5 & 80 \\
\hline 4 & 2.5 & 80 \\
\hline 6 & 2.1 & 83.2 \\
\hline 8 & 1.8 & 85.6 \\
\hline 10 & 1.5 & 88 \\
\hline 12 & 1.12 & 91.04 \\
\hline
\end{tabular}

Tabe 2 Percentage of removal (Experimental Results)

VARYING DOSAGE AND CONTACT TIME

\begin{tabular}{|c|c|c|c|c|c|c|c|}
\hline $\begin{array}{c}\text { Time } \\
\text { (hours } \\
\mathbf{1}\end{array}$ & $\begin{array}{c}\mathbf{0} \\
\mathbf{g m}\end{array}$ & $\begin{array}{c}\mathbf{3} \\
\mathbf{g m}\end{array}$ & $\begin{array}{c}\mathbf{6} \\
\mathbf{g m}\end{array}$ & $\begin{array}{c}\mathbf{9} \\
\mathbf{g m}\end{array}$ & $\begin{array}{c}\mathbf{1 2} \\
\mathbf{g m}\end{array}$ & $\begin{array}{c}\mathbf{1 5} \\
\mathbf{g m}\end{array}$ & $\begin{array}{c}\mathbf{1 8} \\
\mathbf{g m}\end{array}$ \\
\hline 0.5 & 12.5 & 6.16 & 4.8 & 3.75 & 2.7 & 1.51 & 0.84 \\
\hline 1 & 12.5 & 5.7 & 4.69 & 3.53 & 2.44 & 1.46 & 0.52 \\
\hline 1.5 & 12.5 & 5.58 & 4.62 & 3.5 & 2.41 & 1.4 & 0.48 \\
\hline 2 & 12.5 & 5.52 & 4.48 & 3.28 & 2.38 & 1.23 & 0.43 \\
\hline 2.5 & 12.5 & 5.39 & 4.3 & 3.2 & 2.24 & 0.92 & 0.40 \\
\hline 3 & 12.5 & 5.32 & 4.26 & 3.16 & 2.16 & 0.75 & 0.36 \\
\hline 4 & 12.5 & 5.28 & 4.15 & 3.1 & 2.12 & 0.43 & 0.31 \\
\hline 5 & 12.5 & 5.22 & 4.0 & 2.94 & 1.87 & 0.39 & 0.2 \\
\hline 6 & 12.5 & 5.1 & 3.8 & 3 & 1.7 & 0.3 & 0.2 \\
\hline
\end{tabular}

Tabe 3 Varying dosage and contact period (Exp results)

\section{VARYING PH}

\begin{tabular}{|c|c|c|c|c|c|c|}
\hline $\mathbf{2}$ & $\mathbf{4}$ & $\mathbf{6}$ & $\mathbf{7}$ & $\mathbf{8}$ & $\mathbf{1 0}$ & $\mathbf{1 2}$ \\
\hline 0.31 & 0.66 & 0.97 & 1.23 & 1.5 & 2.04 & 3.8 \\
\hline 97.52 & 94.72 & 92.24 & 90.16 & 88 & 83.68 & 69.6 \\
\hline
\end{tabular}

Tabe 4 Varying pH, Residual Fluorine, Removal efficiency

EGG SHELLS (VARYING CONTACT TIME)

\begin{tabular}{|c|c|c|}
\hline $\begin{array}{c}\text { Contact period } \\
\text { (hrs) }\end{array}$ & Residual fluoride & $\begin{array}{c}\text { Percentage of } \\
\text { removal }\end{array}$ \\
\hline
\end{tabular}

\begin{tabular}{|c|c|c|}
\hline 0.5 & 2.81 & 77.52 \\
\hline 1 & 1.97 & 84.24 \\
\hline 2 & 1.56 & 87.52 \\
\hline 3 & 1.35 & 89.2 \\
\hline 4 & 1.04 & 91.68 \\
\hline 6 & 0.93 & 92.56 \\
\hline 8 & 0.73 & 94.16 \\
\hline 10 & 0.55 & 95.6 \\
\hline 12 & 0.32 & 97.44 \\
\hline
\end{tabular}

Tabe 5 Varying pH (Experimental Results)

\section{VARYING DOSAGE AND CONTACT TIME}

\begin{tabular}{|c|c|c|c|c|c|c|c|}
\hline $\begin{array}{c}\text { Time } \\
\text { (hours) }\end{array}$ & $\begin{array}{c}\mathbf{0} \\
\mathbf{g m}\end{array}$ & $\begin{array}{c}\mathbf{3} \\
\mathbf{g m}\end{array}$ & $\begin{array}{c}\mathbf{6} \\
\mathbf{g m}\end{array}$ & $\begin{array}{c}\mathbf{9} \\
\mathbf{g m}\end{array}$ & $\begin{array}{c}\mathbf{1 2} \\
\mathbf{g m}\end{array}$ & $\begin{array}{c}\mathbf{1 5} \\
\mathbf{g m}\end{array}$ & $\begin{array}{c}\mathbf{1 8} \\
\mathbf{g m}\end{array}$ \\
\hline 0.5 & 12.5 & 6.13 & 4.66 & 2.93 & 2.45 & 2.17 & 1.74 \\
\hline 1 & 12.5 & 5.68 & 4.21 & 2.15 & 1.73 & 1.69 & 1.27 \\
\hline 1.5 & 12.5 & 5.06 & 3.94 & 1.72 & 1.56 & 1.34 & 0.95 \\
\hline 2 & 12.5 & 4.78 & 3.28 & 1.49 & 1.35 & 1.07 & 0.56 \\
\hline 2.5 & 12.5 & 4.17 & 2.91 & 1.31 & 1.04 & 0.83 & 0.33 \\
\hline 3 & 12.5 & 3.89 & 2.37 & 1.09 & 0.93 & 0.56 & 0.29 \\
\hline 4 & 12.5 & 3.46 & 2.03 & 0.86 & 0.73 & 0.41 & 0.18 \\
\hline 5 & 12.5 & 3.05 & 1.96 & 0.77 & 0.55 & 0.33 & 0.17 \\
\hline 6 & 12.5 & 2.84 & 1.52 & 0.58 & 0.32 & 0.20 & 0.17 \\
\hline
\end{tabular}

Tabe 6 Varying dosage and contact period (Exp results)

\section{CONCLUSION}

These studies shows that the thermally treated adsorbents of rice husk and eggshells are ideal for fluoride expulsion. The operational parameters, for instance, adsorbent portion, contact time and $\mathrm{pH}$ were found to influence the adsorption productivity. Under perfect conditions adsorbents organized from rice husk and eggshells indicated a high capability of 90 to 89 percent of fluoride extraction individually. For a hidden gathering of $12.5 \mathrm{mg} / \mathrm{l}$. eggshell supposedly was impressively more effective than rice husk with respect to time and adsorbent part required. So it can be said that the sustainable technique is more or less same as that of the conventional technique (Nalgonda technique) in terms of removal efficiencies. However these sustainable materials can only be used in small plants due to absence of mass plantation, which is observed as one of the the major hinderances for it's effective use.

\section{REFERENCES}

1. Fawell J.K. (2006). Fluoride in drinking water. WHO, IWA publishing, London, UK, 144.

2. Brindha K. and Elango L. (2011). Fluoride in groundwater: Causes, implications and mitigation measures. Monroy SD (ed) Fluoride properties, applications and environmental management, 
Nova Science Publishing, 111-136.

3. Bhattacharya H.N. and Chakrabarti S. (2011). Incidence of fluoride in the groundwater of Purulia district, West Bengal: A geo-environmental appraisal. Curr. Sci., 101(2), 152-155.

4. Suthar S., Garg V.K., Jangir S., Kaur S., Goswami N. and Singh S. (2008). Fluoride contamination in drinking water in rural habitations of Northern Rajasthan, India. Environ. Monit. Asses., 145(1-3), 1-6.

5. EPA. (1997). Public health global for fluoride in drinking water. Pesticide and Environmental Toxicology, Section Office of Environmental Health Hazard Assessment, Environmental Protection Agency, California, USA.

6. Ramanaiah S.V ., Mohan S.V ., Rajkumar B. and Sarma P . N. (2006). Monitoring of fluoride concentration in ground water of Prakasham district in India: correlation with physico-chemical parameters. Journal of Environmental science and Engineering, 48(2), 129.

7. WHO (2006). Guidelines for drinking-water quality. first addendum to third edition, 1, recommendations. WHO Press, 20 Avenue Appia, 1211 Geneva 27, Switzerland.

8. Andezhath S.K., Susheela A.K. and Ghosh G. (2000). Fluorosis management in India: the impact due to networking between health and rural drinking water supply agencies. Interdiscip. Perspect. Drink. Water Risk Assess. Manag., 260, 159-165.

9. Chatterjee A., Roy R.K., Ghosh U.C., Pramanik T., Kabi S.P. and Biswas K. (2008). Fluoride in water in parts of Raniganj Coalfield, West Bengal. Curr. Sci., 94(3), 309-311.

10. Salve P.R., Maurya A., Kumbhare P.S., Ramteke D.S. and Wate S.R. (2008). Assessment of groundwater quality with respect to fluoride. Bulletin of environmental contamination and toxicology, 81(3), 289.

11. Sankararamakrishnan N., Sharma A.K. and Iyengar L. (2008). Contamination of nitrate and fluoride in ground water along the Ganges Alluvial Plain of Kanpur district, Uttar Pradesh, India. Environmental monitoring and assessment, 146(1-3), 375-382.

12. Mishra P.C., Meher K., Bhosagar D. and Pradhan K. (2009). Fluoride distribution in different environmental segment at Hirakud Orissa (India). Afr. J. Environ. Sci. Technol., 3(9), 260-264.

13. Kundu M.C. and Mandal B. (2009). Agricultural activities influence nitrate and fluoride contamination in drinking groundwater of an intensively cultivated district in India. Water Air Soil Pollut., 198(1-4), 243-252.

14. Brindha K., Rajesh R., Murugan R. and Elango L. (2011). Fluoride contamination in groundwater in parts of Nalgonda District, Andhra Pradesh, India. Environ. Monit. Assess., 172(1-4), 481-492.

15. Dar M.A., Sankar K. and Dar I.A. (2011). Fluorine contamination in groundwater: a major challenge. Environ. Monit. Assess., 173(1-4), 955-968.

16. Chakrabarti S. and Bhattacharya H.N. (2013). Inferring the hydro-geochemistry of fluoride contamination in Bankura district, West Bengal: A case study. J. Geol. Soc. India, 82(4), 379-391.

17. Samal A.C., Bhattacharya P., Mallick A., Ali M.M., Pyne J. and Santra S.C. (2015). A study to investigate fluoride contamination and fluoride exposure dose assessment in lateritic zones of West Bengal, India. Environ. Sci. Pollut. Res., 22(8), 6220-6229.

18. Bhattacharya P. (2016). Analysis of fluoride distribution and community health risk in Purulia district of West Bengal, India. In Proceedings of the 9th National Level Science Symposium organized by the Christ College, 3, 88-92.

19. Lirong X., Luo K., Feng F. and Tan J. (2006). The chemical mobility of fluorine in rocks. Fluoride, 39(2), 145-151.

20. Hem J.D. (1985). The study and interpretation of the chemical characteristics of natural water. 3rd edition, US Geological Survey Water Supply Paper, 2254

21. Apambire W.B., Boyle D.R. and Michel F.A. (1997). Geochemistry, genesis and health implications of fluoriferous groundwater in the upper regions of Ghana. Environ. Geol., 33(1), 13-24.

22. Saxena V. and Ahmed S. (2003). Inferring chemical parameters for the dissolution of fluoride in groundwater. Environ. Geol., 43(6), 731-736.

23. Allen-Long L.S. (2001). Microbial effect on weathering of apatite minerals for phosphorus. Geological Society of America, North-Central Section, 35th Annual Meeting.

24. Bade Sai Teja Reddy, A. Aravindan, 'Electrolytic Defluoridation Technique in Sustainable Manner for Removal of Flouride in Groundwater', International Journal of Recent Technology and Engineering (IJRTE) ISSN: 2277-3878, Volume-7, Issue-6C2, (April 2019), 370-373.
25. Y. Raja Venkata Sabith Chandra, 'A. Aravindan, 'Assessment of Ground Water Quality Near Municipal Waste Dumpy yard in Kanuru, Vijayawada, Andhra Pradesh, India', International Journal of Recent Technology and Engineering (IJRTE) ISSN: 2277-3878, Volume-7, Issue-6C2, (April 2019), 266-269.

26. Surisetti Vamsi Harischandra Prasad, A. Aravindan, Koya Naga Venkata Siva Prasad, 'Sustainability of Gosthani River and Design of Sewage Treatment Plant for Tanuku Town, West Godavari District, Andhra Pradesh, India', International Journal of Recent Technology and Engineering (IJRTE) ISSN: 2277-3878, Volume-7, Issue-6C2, (April 2019), 106-113.

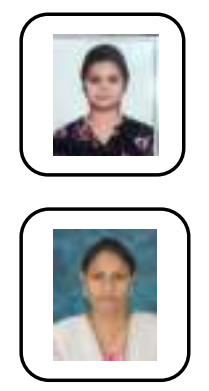

\section{AUTHORS PROFILE}

Susmitha Sambaraju is pursuing her B.Tech at Koneru Lakshmaih Education Foundation (Deemed to be university), Vaddeeswaram, Guntur District, Andhra Pradesh, 522502, India.

Sree Lakshmi is working as Assistant Professor at Koneru Lakshmiah Education Foundation (Deemed to be University), Vaddeswaram, Guntur district, AndhraPradesh, India. She has completed Master of Engineering in Environmental Engineering from Andhra University college of Engineering and Bachelor of Technology in Civil Engineering from DMSSVH College of Engineering, Machilipatnam. She has published 3 research papers in international journals and conferences and guided 2 number of masters and 10 number of Bachelor's dissertation work. 